\begin{tabular}{|c|c|c|}
\hline & $\begin{array}{c}\text { Bioeduca: Journal of Biology Education } \\
\text { http://journal.walisongo.ac.id/index.php/bioeduca } \\
\text { ISSN 2086-9324 (print) }\end{array}$ & BBOEDUCA \\
\hline$\amalg_{\text {WALISONGO }}$ & $\begin{array}{c}\text { Volume 1, Nomor 1, Tahun } 2019 \\
\text { Hal. } 38-45\end{array}$ & \\
\hline
\end{tabular}

\title{
Pengaruh Persepsi Siswa Tentang Ketersediaan dan Pemanfaatan Fasilitas Laboratorium IPA Terhadap Motivasi Belajar IPA-Biologi Siswa Kelas VIII
}

\author{
Nila Fadlilah ${ }^{1^{*}}$, Kusrinah ${ }^{2}$, Anif Rizqianti Hariz ${ }^{3}$ \\ ${ }^{1,3}$ Pendidikan Biologi, Universitas Islam Negeri Walisongo Semarang \\ ${ }^{2}$ Biologi, Universitas Islam Negeri Walisongo Semarang \\ *Email: nilafadlilah754@gmail.com
}

\begin{tabular}{|c|c|}
\hline Informasi Artikel & ABSTRAK \\
\hline $\begin{array}{l}\text { Submit: } 10-08-2019 \\
\text { Diterima: } 12-08-2019 \\
\text { Dipublikasikan: } 31-09-2019\end{array}$ & 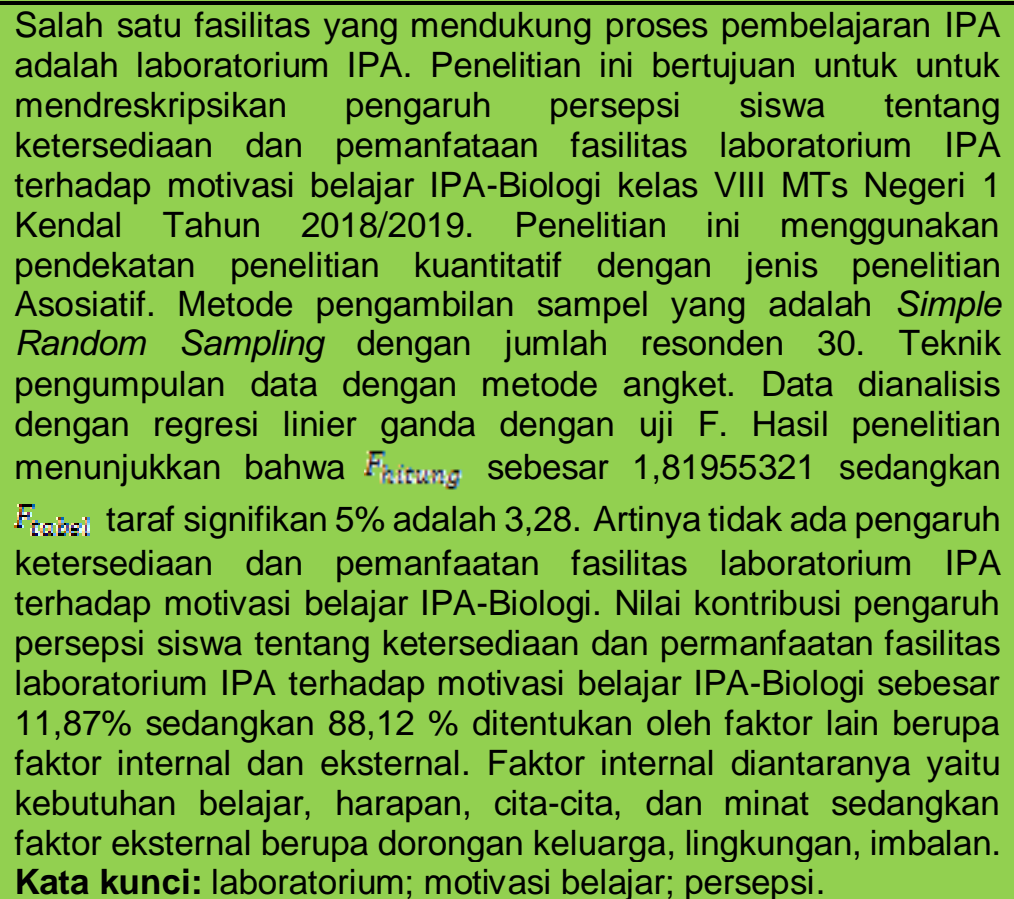 \\
\hline Penerbit & ABSTRACT \\
\hline $\begin{array}{l}\text { Program Studi Pendidikan } \\
\text { Biologi, Fakultas Sains dan } \\
\text { Teknologi, UIN Walisongo } \\
\text { Semarang }\end{array}$ & $\begin{array}{l}\text { One facility that can support the science learning process is a } \\
\text { science laboratory. This study aims to describe the influence of } \\
\text { student perceptions about the availability and utilization of } \\
\text { researcher uses a quantitative research approach with the type } \\
\text { of associative research. The sampling method is Simple Random } \\
\text { Sampling with the number of respondents } 30 \text {. Data collection } \\
\text { techniques using the questionnaire method. This study uses } \\
\text { multiple linear regression data analysis with F test. The results of } \\
\text { the study show that it is } 1,81955321 \text { while the significant level of } \\
5 \% \text { is } 3,28 \text {. Because this value means that Ho is accepted. This } \\
\text { means that there is no influence on the availability and utilization } \\
\text { of science laboratory facilities on science-Biology learning } \\
\text { motivation. The value of the contribution of the students' } \\
\text { perceptions about the availability and utilization of science } \\
\text { laboratory facilities on science-Biology learning motivation is } \\
11.87 \% \text { while } 88.12 \% \text { is determined by other factors which are } \\
\text { sometimes in the form of internal and external factors. Internal }\end{array}$ \\
\hline
\end{tabular}

Nila Fadlilah et al. - Pengaruh Persepsi Siswa Tentang Ketersediaan dan Pemanfaatan Fasilitas Laboratorium IPA Terhadap Motivasi Belajar IPA-Biologi Siswa Kelas VIII 
factors include learning needs, hopes and ideals, interests while external factors in the form of family encouragement, environment, reward.

Keywords: laboratory; learning motivation; perception. Copyright (C2019, Bioeduca: Journal of Biology Education

\section{PENDAHULUAN}

Pendidikan bukan sekedar memberikan pengetahuan atau keterampilan. Pendidikan berfungsi mengembangkan potensi yang dimiliki peserta didik. Untuk membantu mengembangkan potensi peserta didik, diharapkan dalam proses interaktif, menyenangkan, memotivasi peserta didik. Saat ini menunjukkan masih adanya kesenjangan mutu pendidikan. Kesenjangan mutu pendidikan disebabkan faktor pemanfaatan fasilitas sekolah yang belum maksimal, sumber daya manusia yang masih terbatas dan kurikulum yang belum siap untuk dipergunakan dalam pembelajaran. Dalam Al-Qur'an juga membahas tentang pendidikan seperti yang dijelaskan dalam firman Allah Q.S Al-Ankabut ayat 43, berbunyi:

\section{"Dan perumpamaan-perumpamaan ini kami buat untuk manusia dan tiada yang} memahaminya kecuali orang-orang berilmu" (Departemen Agama, 2004)"

Pendidikan yang baik adalah pendidikan yang dapat memfasilitasi peserta didik secara maksimal sehingga mampu berkontribusi positif untuk perkembangan serta pembangunan nasional. Salah satu fasilitas yang dapat mendukung proses pembelajaran adalah laboratorium. Laboratorium diartikan sebagai suatu tempat dilakukannya kegiatan percobaan dan penelitian. Laboratorium sangat diperlukan sebagai tempat belajar untuk lebih mempelajari sesuatu, seperti pengetahuan tentang percobaan secara langsung dan memberikan pengalaman yang nyata pada siswa sebagai salah satu faktor pendukung pelaksanaan pembelajaran. Pemanfaatan laboratorium dalam proses pembelajaran diharapkan dapat dilaksanakan dengan semestinya.

Berdasarkan wawancara dengan guru IPA di MTs Negeri 1 Kendal Ahmad Yanuar Habibur, S.Pd pada tanggal 11 Januari 2018 di ruang Laboratorium IPA, siswa kelas VIII belum memanfaatkan adanya fasilitas laboratorium IPA sebagai media pembelajaran secara maksimal. Hal ini dikarenakan kurangnya waktu untuk mengadakan kegiatan praktikum. Pemanfaatan laboratorium atau kegiatan praktikum merupakan bagian dari proses belajar mengajar. Melalui kegiatan praktikum, siswa dapat membuktikan konsep atau teori yang sudah ada dan dapat melakukan percobaan sendiri, mengembangkan kemampuan menemukan masalah, mencari alternatif pemecahan masalah, membuat kesimpulan, dan dapat mengkomunikasikan hasil percobaan baik secara lisan maupun tertulis. Selain itu, siswa juga mengambil kesimpulan sehingga dapat menunjang pemahaman mahasiswa terhadap mata pelajaran IPA. Dalam hal ini, diharapkan siswa lebih termotivasi untuk belajar IPA. Adanya kegiatan praktikum, siswa diberi kesempatan untuk memenuhi dorongan rasa ingin tahu dalam kegiatan praktikum.

Hasil observasi pada saat kegiatan pembelajaran pada hari Sabtu, tanggal 6 
Januari di MTs Negeri 1 Kendal, terlihat saat proses pembelajaran siswa tidak memperhatikan ketika guru sedang menjelaskan pelajaran dan banyak melakukan aktivitas lain di luar pembelajaran. Hal tersebut dikarenakan kegiatan pembelajaran hanya menggunakan metode ceramah dengan bahan ajar buku paket sehingga siswa kurang memahami materi. Tidak tersedianya waktu yang cukup mengakibatkan guru tidak melakukan kegiatan praktikum sehingga pemahaman siswa kurang dan motivasi belajar IPA kurang.

Faktor yang mempengaruhi proses dan hasil belajar siswa adalah faktor lingkungan, faktor instrumental, kondisi fisiologis dan kondisi psikologis. Faktor psikologis adalah faktor yang utama mempengaruhi proses dan hasil belajar anak didik. Salah satu faktor psikologis adalah motivasi (Rohmah, Noer, 2012). Motivasi belajar IPA dapat ditingkatkan dengan adanya fasilitas yang lengkap yang dapat menunjang proses pembelajaran. Melalui kegiatan praktikum dengan memanfaatkan fasilitas laboratorium siswa dapat meningkatkan kemampuan proses, kemampuan menyelesaikan masalah, dan meningkatkan motivasi serta sikap siswa dalam proses belajar. Penggunaan fasilitas sekolah saat kegiatan pembelajaran sangat penting dalam memperlancar pelaksanaan proses belajar mengajar untuk mendreskripsikan pengaruh persepsi siswa tentang ketersediaan dan pemanfataan fasilitas laboratorium IPA terhadap motivasi belajar IPA-Biologi kelas VIII MTs Negeri 1 Kendal Tahun 2018/2019.

\section{METODE PENELITIAN}

Penelitian ini merupakan penelitian kuantitatif. Pendekatan penelitian kuantitatif yang digunakan adalah penelitian asosiatif. Penelitian ini dilakukan di MTs Negeri 1 Kendal dengan populasi semua siswa kelas VIII MTs Negeri 1 Kendal. Sampel dalam penelitian ini diambil 30 siswa secara Random Sampling.

Variabel bebas dalam penelitian ini adalah persepsi siswa tentang ketersediaan dan pemanfaatan fasilitas laboratorium IPA. Variabel terikat dalam penelitian ini adalah motivasi belajar IPA-Biologi siswa kelas VIII MTs Negeri 1 Kendal Tahun Ajaran 2018/2019. Metode pengumpulan data yang digunakan dalam penelitian ini adalah metode teknik kuesioner (Angket), teknik dokumentasi, observasi dan wawancara tidak terstruktur.

\section{HASIL PENELITIAN DAN PEMBAHASAN}

\section{A. Analisis Data Tahap Awal}

Berdasarkan hasil uji normalitas data awal persepsi siswa tentang ketersediaan laboratorium IPA diperoleh hasil terlihat pada Tabel 1 berikut:

Tabel 1. Hasil Uji Normalitas Tahap Awal

\begin{tabular}{lcccc}
\hline & Variabel & $\begin{array}{c}\text { Taraf } \\
\text { Signifikan }\end{array}$ & $\begin{array}{c}\text { Nilai } \\
\text { Signifikan }\end{array}$ & Kriteria \\
\hline $\begin{array}{l}\text { Persepsi siswa } \\
\text { ketersediaan laboratorium IPA }\end{array}$ & 11,070 & 4,7790 & Normal \\
\hline
\end{tabular}

Berdasarkan Tabel 1 dapat diketahui bahwa persepsi tentang ketersediaan berdistribusi normal karena $\mathrm{x}^{2}$ hitung $<\mathrm{x}^{2}$ tabel 


\section{B. Analisis Data Tahap Akhir}

Hasil uji normalitas nilai persepsi siswa tentang ketersediaan, pemanfaatan fasilitas dan motivasi belajar diperoleh hasil pada Tabel 2 berikut:

Tabel 2. Hasil Uji Normalitas

\begin{tabular}{lllll}
\hline No & \multicolumn{1}{c}{ Variabel } & $\begin{array}{c}\text { Taraf } \\
\text { Signifikansi }\end{array}$ & $\begin{array}{c}\text { Nilai } \\
\text { Signifikan }\end{array}$ & Kriteria \\
\hline 1 & $\begin{array}{l}\text { Ketersediaan } \\
\text { laboratorium IPA (X1) }\end{array}$ & 11,070 & 4,7851 & Normal \\
\hline 2 & $\begin{array}{l}\text { Pemanfaatan fasilitas } \\
\text { laboratorium IPA (X2) }\end{array}$ & 11,070 & 4,7790 & Normal \\
\hline 3 & Motivasi belajar IPA-Biologi $(\mathrm{Y})$ & 11,070 & 4,4166 & Normal \\
\hline
\end{tabular}

Dari tabel 2 diketahui bahwa $x^{2}$ hitung ketiga variabel sebagai data pada penelitian ini kurang dari $\mathrm{x}^{2}$ tabel sehingga $\mathrm{HO}$ ditolak dan menerima $\mathrm{Ha}$.

Berdasarkan perhitungan skor angket persepsi siswa tentang ketersediaan laboratorium IPA 50,52\% yang menunjukan bahwa persepsi siswa tentang ketersediaan laboratorium IPA di MTs Negeri 1 Kendal memiliki kategori persepsi siswa tentang ketersediaan laboratorium IPA "Cukup".

Menurut Tim Ahli Program STEP-2 (2007) suatu laboratorium harus memiliki sarana perabot seperti meja, kursi, lemari untuk menyimpan alat, bahan, dan rak. Selain itu laboratorium juga harus memiliki alat peraga pendidikan seperti mikroskop, neraca analitik, $\mathrm{pH}$ meter dan alat dari gelas. Alat laboratorium dari gelas yang umum dimiliki oleh laboratorium sekolah adalah gelas ukur, gelas piala, labu erlenmenyer, labu ukur, pipet tetes, pipet ukur, gelas arloji, pipet gondok, corong, tabung reaksi dan cawan petri. Selain alat-alat laboratorium juga harus memiliki zat atau bahan seperti asam klorida, amoniak pekat, dan eter.

MTs Negeri 1 Kendal sudah mempunyai laboratorium IPA. Akan tetapi dalam penggunaannya sebagai tempat praktikum IPA belum maksimal. Laboratorium IPA yang dimiliki oleh MTs Negeri 1 Kendal juga sudah dilengkapi dengan perabot seperti meja, kursi dan lemari penyimpanan alat dan bahan. Selain itu laboratorium di MTs Negeri 1 Kendal juga mempunyai alat-alat laboratorium yang terbuat dari kaca seperti corong, pipet tetes, cawan petri, gelas ukur, labu erlenmenyer, tabung reaksi, gelas arloji, dan pipet ukur. Laboratorium IPA juga memiliki alat peraga pendidikan seperti torso sistem pencernaan, kulit, torso sistem indra penglihatan, sistem rangka dan mikroskop.

Tabel 3. Daftar Alat-alat di Laboratorium IPA MTs Negeri 1 Kendal

\begin{tabular}{clcl}
\hline No & \multicolumn{1}{c}{ Nama Barang } & No & \multicolumn{1}{c}{ Nama Barang } \\
\hline 1 & Mortar & 14 & Kotak genetika \\
2 & Pestle & 15 & Gelas Arloji \\
3 & Plat Tetes & 16 & Labu Ukur \\
4 & Rak Tabung & 17 & 1 kotak Gelas Objek \\
5 & Mikroskop Cahaya & 18 & 1 Kotak Preparat Awetan \\
6 & Gelas Beker & 19 & Gambar Anatomi Kerangka
\end{tabular}

Nila Fadlilah et al. - Pengaruh Persepsi Siswa Tentang Ketersediaan dan Pemanfaatan Fasilitas Laboratorium IPA Terhadap Motivasi Belajar IPA-Biologi Siswa Kelas VIII 


\begin{tabular}{clcl}
\hline No & \multicolumn{1}{c}{ Nama Barang } & No & \multicolumn{1}{c}{ Nama Barang } \\
\hline & Pipet Tetes & 20 & Manusia \\
8 & Tabung Erlenmenyer & 21 & Torso Kerangka Manusia \\
9 & Bunsen & 22 & Globe \\
10 & Kaki Tiga & 23 & Torso Kulit \\
11 & Corong & 24 & Torso Mata \\
12 & Tabung Gelas & 25 & Torso Jantung \\
13 & Pinset & 26 & Gambar Jantung \\
\hline
\end{tabular}

Tabel 4. Daftar Perabot di Laboratorium IPA MTs Negeri 1 Kendal

\begin{tabular}{cl}
\hline No & \multicolumn{1}{c}{ Nama Barang } \\
\hline 1 & Lemari Penyimpanan Alat \\
2 & Lemari Penyimpanan Torso \\
3 & Kotak Penyimpanan Mikroskop \\
4 & Kursi Praktikum \\
5 & Meja Praktikum \\
6 & Bak Cuci \\
7 & Meja Demonstrasi \\
\hline
\end{tabular}

Tabel 5. Daftar Perlengkapan Lain MTs Negeri 1 Kendal

\begin{tabular}{cl}
\hline No & Nama Barang \\
\hline 1 & Alat Pemadam Kebakaran \\
2 & Peralatan P3K \\
3 & Papan Tulis dan Sepidol \\
4 & Jam Dinding \\
5 & Kipas Angin \\
6 & Struktur Organisasi \\
7 & Tata Tertib \\
\hline
\end{tabular}

Berdasarkan skor perhitungan pemanfaatan fasilitas laboratorium IPA sebesar $64,91 \%$ yang menunjukkan bahwa pemanfaatan fasilitas laboratorium IPA memiliki kategori pemanfaatan fasilitas laboratorium IPA yakni "Baik". Dari hasil perhitungan persentase pemanfaatan fasilitas laboratorium IPA, di MTs Negeri 1 Kendal memiliki kategori baik. Hal ini dikarenakan laboratorium di MTs Negeri 1 Kendal sudah memiliki fasilitas yang sesuai dengan teori Muliawan (2018) yaitu fasilitas laboratorium IPA meliputi instalasi air (bak dan kran air), jaringan listrik, saluran gas, kipas angin, ventilasi, meja, kursi, rak, papan tulis, alat pemadam kebakaran, kotak obat-obatan dan peralatan P3K.

Perhitungan persentase motivasi belajar IPA-Biologi rata-rata persentasenya yaitu $14,10 \%$ yang menunjukan bahwa siswa MTs Negeri 1 Kendal memiliki kategori motivasi belajar IPA-Biologi yang "Sangat kurang". Kurangnya motivasi belajar ini dikarenakan siswa kelas VIII baru pertama kali melakukan kegiatan praktikum. Motivasi adalah kekuatan yang menjadi pendorong kegiatan individu yang menunjukan kondisi dalam diri individu yang mendorong individu untuk melakukan kegiatan yang mencapai tujuan. Motivasi memiliki peranan yang penting dalam proses pembelajaran karena motivasi merupakan tenaga yang menggerakan dan mengarahkan kegiatan siswa untuk belajar (Suprihatiningrum, Jamil 2016). Munculnya motivasi belajar dalam diri peserta didik juga sangat dipengaruhi oleh 
faktor internal misalnya faktor dari guru. Motivasi merupakan faktor penentu dan berfungsi menimbulkan, mendasari dan menggerakkan perbuatan. Motivasi dapat menentukan baik tidaknya dalam mencapai tujuan sehingga semakin besar motivasi maka semakin besar kesuksesan yang akan diperoleh.

Untuk mengetahui adakah pengaruh antara variabel persepsi siswa tentang ketersediaan laboratorium IPA dan pemanfaatan fasilitas laboratorium IPA terhadap motivasi belajar IPA-Biologi terlebih dahulu harus diuji keberartian regresi dengan mengajukan hipotesis:

Ho : Persamaan regresi ganda tidak berati

$\mathrm{Ha}$ : Persamaan regresi ganda berarti

Dari perhitungan diperoleh harga $F_{\text {hitung }}$ adalah 1,82 sedangkan harga $F_{\text {tabel }}$ untuk dk pembilang 2 dan dk penyebut 28 serta taraf signifikansi $5 \%$ adalah 3,34. Karena $F_{\text {hitung }}<F_{\text {tabel }}$ maka $\mathrm{HO}$ diterima, sehingga dapat disimpulkan bahwa persamaan: $\hat{Y}=46,1788724+0,1967396 X_{1}+0,200893 X_{2}$ tidak berati

Koefisien korelasi antara persepsi siswa tentang ketersediaan laboratorium IPA $\left(X_{1}\right)$ dan pemanfaatan fasilitas laboratorium IPA $\left(X_{2}\right)$ terhadap motivasi belajar IPA-Biologi $(Y)$ diperoleh nilai $R=0,344$. Hal ini menunjukkan korelasi yang positif antara persepsi sisw tentang ketersediaan dan pemanfaatan fasilitas laboratorium IPA terhadap motivasi belajar IPA-Biologi termasuk dalam kategori rendah.

Hasil dari perhitungan koefisien korelasi ganda pada regresi ganda diketahui $R$ hitung adalah 0,344 sedangkan $R$ tabel adalah 0.361 lebih kecil dari $R$ tabel maka artinya tidak ada hubungan yang signifikan antara persepsi siswa tentang ketersediaan dan pemanfaatan fasilitas laboratorium IPA terhadap motivasi belajar IPA-Biologi.

Penelitian ini berbeda dengan hasil penelitian yang dilakukan oleh Yuliana et al. (2017) yang menunjukkan bahwa motivasi belajar IPA dengan memanfaatkan laboratorium IPA meningkat dilihat dari angket motivasi posttest siswa setelah pembelajaran. Berdasarkan perhitungan KD (koefisien Determinasi) adalah 11,88 \% artinya pengaruh persepsi siswa tentang ketersediaan dan pemanfaatan fasilitas laboratorium IPA terhadap motivasi belajar IPA-Biologi peserta didik sebesar 11,88\%.

Perhitungan dan analisis dapat memberikan gambaran bahwa persepsi siswa tentang ketesediaan dan pemanfaatan fasilitas laboratorium IPA tidak terdapat signifikansi terhadap motivasi belajar IPA-Biologi siswa kelas VIII MTs Negeri 1 Kendal. Persepsi siswa tentang ketersediaan laboratorium IPA di MTs Negeri 1 Kendal memiliki kategori cukup dan pemanfaatan fasilitas laboratorium IPA memilliki kategori baik. Akan tetapi motivasi belajar siswa memilki kategori sangat kurang. Hal ini dikarenakan siswa baru pertama kali melaksanakan kegiatan praktikum dengan memanfaatkan laboratorium IPA yang ada di sekolahan.

Motivasi belajar dapat timbul karena faktor intrinsik berupa hasrat dan keinginan berhasil dan dorongan kebutuhan belajar harapan dan cita-cita. Faktor ekstrinsik yang mempengaruhi motivasi belajar adalah adanya penghargaan, lingkungan belajar yang kondusif, dan kegiatan belajar yang menarik. Tetapi kedua 
faktor tersebut disebabkan oleh rangsangan tertentu, sehingga seseorang berkeinginan untuk melakukan aktivitas belajar yang lebih giat dan semangat (Suprihatingrum, Jamil 2016).

\section{SIMPULAN DAN SARAN}

Berdasarkan hasil penelitian yang telah dilakukan tentang pengaruh persepsi siswa tentang ketersediaan dan pemanfaatan fasilitas laboratorium IPA terhadap motivasi belajar IPA-Biologi siswa kelas VIII MTs Negeri 1 Kendal Tahun Ajaran 2018/2019 dapat disimpulkan bahwa tidak terdapat pengaruh yang signifikan antara persepsi siswa tentang ketersediaan dan pemanfaatan fasilitas laboratorium IPA terhadap motivasi belajar IPA-Biologi siswa kelas VIII MTs Negeri 1 Kendal Tahun Ajaran 2018/2019.

\section{UCAPAN TERIMA KASIH}

Penulis mengucapkan terimakasih kepada semua pihak yang telah membantu penelitian ini dapat terlaksana dengan baik yakni MTsN 1 Kendal.

\section{RUJUKAN}

Akinbobola AO \& Folashade A. (2010). Analysis of science process skills in West African senior secondary school certificate physics practical examinations in Nigeria. American-Eurasian Journal of Scientific Research, 5 (4): 234-240.

Departemen Agama. (2004). Al-Qur'an dan Terjemahannya. Surabaya: Mekar Surabaya.

Hayat MS., Anggraeni, S., \& Redjeki, S. (2010). Pembelajaran berbasis praktikum pada konsep invertebrata untuk mengembangkan sikap ilmiah siswa. Bioma, 1(2): 141152.

Hikmah, N., Sandewi, N., \& Agung, S. (2017). Penerapan Laboratorium Virtual untuk Meningkatkan Pemahaman Konsep Siswa. EduChimia: Jurnal Kimia dan Pendidikan Kimia, 2(2): 186 - 195.

Kusdiastuti, M., Harjono, A., Sahidu, H., \& G, Gunawan. (2016). Pengaruh Model Pembelajaran Inkuiri Berbantuan Laboratorium Virtual Terhadap Penguasaan Konsep Fisika Peserta Didik. Jurnal Pendidikan Fisika dan Teknologi, 11(3): 116 $-122$.

Litasari, K.N., Setiati, N., \& Herlina, L. (2014). Profil Pembelajaran Biologi Berbasis Laboratorium dan Implikasinya Terhadap Hasil Belajar Siswa di SMA Negeri SeKabupaten Semarang. Journal of Biology Education, 3(2): 172 - 179.

Maretasari, E., Subali, B., \& Hartono. (2012). Penerapan Model Pembelajaran Inkuiri Terbimbing Berbasis Laboratorium untuk Meningkatkan Hasil Belajar dan Sikap Ilmiah Siswa. UPEJ, 1(2): $28-31$.

Muliawan, Wawan. (2018). Teknik Laboratorium. Yogyakarta: Deepublish (CV Budi Utama).

Murdiyahwati E. (2010). Pengaruh Keaktifan Siswa dalam Pembelajaran Berbasis Kegiatan Laboratorium Materi Pokok Biologi Sel Terhadap Hasil Belajar Praktikum Biologi di Kelas XI MAN 1 Semarang. (Skripsi). Semarang: Institut Agama Islam Negeri Walisongo.

Rohmah, Noer. (2012). Psikologi Pendidikan. Yogyakarta: Teras. 
Sudargo FT, \& Soesy AS. (2009). Pembelajaran Biologi Berbasis Praktikum Untuk Meningkatkan Keterampilan Proses dan Kemampuan Berpikir Kritis Siswa SMA. FPMIPA UPI: Laporan Penelitian.

Sugiyono. (2013). Metode Penelitian Pendidikan (Pendekatan Kuantitatif, Kualitatif, dan $R \& D)$. Bandung: Alfabeta.

Sundari, R. (2008). Evaluasi pemanfaatan laboratorium dalam pembelajaran biologi di Madrasah Aliyah Negeri Sekabupaten Sleman. Jurnal Penelitian dan Evaluasi Pendidikan, (XII) 2: 196 - 212

Suprihatiningrum, Jamil. (2016). Strategi Pembelajaran. Yogyakarta: Ar-Ruzz Media.

Tim Ahli Program STEP-2. (2007). Manajemen Laboratorium IPA. Jakarta: Departemen Agama Republik Indonesia. 